\title{
SMALL WATER RESERVOIRS - SOURCES OF WATER OR PROBLEMS?
}

\author{
'́uboš Jurik', Dušan Húska', Klaudia Halászová', Anna Bandlerová1 \\ 1 Department of Water Resources and Environmental Engineering, Slovak University of Agriculture in Nitra, \\ Hospodárska 7, 94976 Nitra, Slovakia, e-mail: lubos.jurik.nr@gmail.com
}

Received: 2015.07.14

Accepted: 2015.08.31

Published: 2015.10.01

\begin{abstract}
The design of small water reservoirs in Slovakia and neighbouring countries has common origins in the middle of the last century. Most of them were an alternative source of water for irrigation of field crops. Nowadays, we have to face new problems, such as the problems with the design of hydrological data and real current discharges, the problems with original and new design of the flood wave for the solution of the safety overflow. All of $\mathrm{Q}_{100}$ flows recorded nowadays are much higher than those which had been designed and built. The safety overflows no longer answer the purpose of the contemporary flows. The problems with the Framework Directive are also important small water reservoirs are not resolved in the Directive as the water bodies of stagnant water because they have an area of less than $0.5 \mathrm{~km}^{2}$. The same problem is also with the preservation of continuity of the flow and the fact that they should let the fish pass. Unfortunately, the state, administrators of small dams, operators and nature conservationists have different points of view on the above-mentioned problems. The article elaborates these problems and suggests possible solutions to the problems.
\end{abstract}

Keywords: water reservoirs, hydrological conditions, water framework directive, river continuum, operation and maintenance.

\section{INTRODUCTION}

The history of building water reservoirs is connected with the beginning of the intensive contribution of human beings to environment and regulation of water conditions. Water reservoirs are joined especially with the necessity to provide water for various purposes to improve, support and protect our life.

In conditions of the Slovak republic, which is considered as hydrological roof of Europe, precipitations represent the majority of the water sources. The rivers, which spring in our territory, are characterised by diversity of water flow especially in the headwater area which is changed by precipitations really quickly. The differences between maximum and minimum water flow is evident and it might be 1000 times stronger. The extreme phenomenon can occur in the mountain streams, which might be totally without water in a particular part of the year.

The tradition of building water reservoirs is not the solution of the recent times. Artificial safety dams, draining and irrigation channels were built by Summers in 4000 b.c. The water reservoir Moereis with water channel from the Nile was built in ancient Egypt 3000 years ago to supply Fajum oasis with water.

What purpose are water reservoirs built for? They provide protection against floods, they serve as the main source of water supplies, they enable the usage of water energy, they serve as water transport vessels and storage volumes for irrigation of agricultural soils, they allow to realise the tourist-recreational services, they serve as fish ponds and significantly contribute to improve the quality of waterbodies.

Apart from positive impacts on the environment, water reservoirs have also negative effects as for example submersion of the most arable soils in specific areas, soaking, through the soil to water reservoir surroundings area, erosion of the reservoir banks and dam slopes. It might cause relocation of road network, urban areas, there exist potential danger of unpredictable destruction of 
Table 1. Overview of the oldest water reservoirs

\begin{tabular}{|l|c|c|c|l|}
\hline \multicolumn{1}{|c|}{ Dam name } & Country & Dam type & Dam height/length of the dam $[\mathrm{m}]$ & \multicolumn{1}{|c|}{ Approximate dating } \\
\hline Moeris & Egypt & earth dam & $8 /-$ & $4-3$ thous. years B.C. \\
\hline Mokhrablur & Armenia & earth dam & $3 / 320$ & $4-3$ thous. years B.C. \\
\hline Jawa & Jordan & earth dam & $5 / 90$ & $4-3$ thous. years B.C. \\
\hline Sad-Rei-Kafra & Egypt & stone wall & $5 / 110$ & 2.6 thous. years B.C. \\
\hline Kofini & Grece & earth dam & $14 / 440$ & 1.3 thous. years B.C. \\
\hline Marib & Jemen & earth dam & $10 / 400$ & 800 years B.C. \\
\hline Kesis Golu & Turkey & gravitational & $18 / 50$ & 800 years B.C. \\
\hline Proserpina & Spain & gravitational & $22 / 427$ & 2 century A.D. \\
\hline Baume & France & arch dam & $12 / 18$ & 2 century A.D. \\
\hline
\end{tabular}

water dams with catastrophic consequences and sediments in water reservoir might be accumulated etc.

The stages of evolution of historical water reservoirs are connected with their purposes they were built for and their dependence on economical demands of societies are relevant to their historical development.

The evolutional stages in Slovakia [Lukáč, 2010] can be divided according the purpose, which water accumulated in water reservoirs, is utilized for:

- utilization of water for the purposes of ore mines from the16-th to the 18-th century,

- utilization of water as a transport medium for the extraction and transportation of timber from the 16-th to the 20-th century,

- utilization of water as the source of production of electric energy from the end of the 19th century,

- utilization of water for agricultural purposes from the 19-th century, especially after 1960.

The oldest constructions in Slovak conditions were built up in Banská-Štiavnice district and they date back to 1510 and 1511 . Subsequent building was realised particularly in the second half of the 16-th and the 17-th century. Those constructions served mainly to breed fish and they were supposed to supply the towns and villages with potable and utility water. The system of water reservoirs, which were used for ore mining and technology of treatment of gold and silver, was built up in vicinity of Banská-Štiavnica district. They mostly served to provide water accumulated in reservoirs to drive pumping machines and conduct water away from mines. Similar constructions were built up only in Norway and Germany in Hartz and Sachsen-Anhalt districts. Among the important energy work of this period belong waterworks system Motyčky - Dolný Jelenec - Staré Hory from the years 1923-1925 belong to the important energy works of this period.

Water reservoirs in Banská-Štiavnica district created economical water system with interesting and unique usage of water from outland basin and the mutual connection of various water reservoirs and the systems of drainage galleries and shafts which enabled multiple utilization of accumulated water.

The follow-up building of water reservoirs in the 19-th century allowed establishing the reclusion- water reservoirs for transportation of timber by rafts. At the beginning of the 20-th century the first water dams which served the purpose of energy production were built up.

\section{SMALL WATER RESERVOIRS}

Small water reservoirs, commonly referred to as artificial reservoirs with lower depth and volume and the flooded area that serve diverse water management requirements. They represent hydraulic structures, created for natural or artificial water accumulation or specific space created by valley dams, fencing parts of the territory or artificial depressions on the surface, and they serve for water management, water accumulation, water retention in the floods, the transformation of flood waves, creating water environment and the modification of the water quality [Šálek, 2000]. Common use of water is for power generation, recreation, navigation, irrigation, municipal and industrial water supply, and instream flows for habitat.

More accurate description refers to STN 736824 - small water reservoirs, (which became effective from 1st May 1979) which includes small water reservoirs and water reservoirs, if 
they comply with the following conditions:

- The storage capacity at the controllable level in reservoir is not higher than 2 million $\mathrm{m}^{3}$.

- The maximum depth of the reservoir does not exceed $9 \mathrm{~m}$ (as far as the maximum level, not considering locally greater depth at the site of the original riverbed).

- Maximum flow $\left(\mathrm{Q}_{100}\right)$ is not greater than $60 \mathrm{~m}^{3} \mathrm{~s}^{-1}$.

STN 736824 is recommended only for reservoirs with a capacity lower than 5 thousand $\mathrm{m}^{3}$ [Jurik, 2011].

According to Technical Standard, reservoirs in Slovakia are divided into three categories:

- reservoirs up to $5000 \mathrm{~m}^{3}$ are small reservoirs which are constructed for many different purposes,

- reservoirs from $5000 \mathrm{~m}^{3}$ to 2 million $\mathrm{m}^{3}$ are small ponds,

- reservoirs with a capacity of more than 2 million $\mathrm{m}^{3}$ are dams.

Reservoirs can be divided according to various criteria. Generally, they comprise dammed in valleys reservoirs and bank-side reservoirs. They might be valley, excavated, recessed and dammed reservoirs, as well. They can be determined by a general location as village, field, meadow or forest reservoirs. We can also label them according to the origin of water as rainy, spring, river and stream water reservoirs. In the broad sense, more wideranging is the division of water reservoirs according to their purpose of utilisation of accumulated water or storage pools of water reservoirs.

Small water reservoirs as reservoirs in Slovak conditions were built as general reservoirs - as village source for fire water, for fish breeding, but especially as irrigation reservoirs. Due to the volatility of water flow in rivers, objects requiring a secure water supply for the implementation of special-purpose activities, the vast majority of irrigation systems were dependent on stable water resources. In the period after 1960, when the first irrigation structures were created, they were connected with the construction of water dams, such as Madunice, Král'ová - 27,000 hectares and Sírava in Eastern Slovakia which ensure irrigation of 143,000 hectares. The smaller systems had their own small water reservoirs. Overall, Slovakia has more than 200 small water reservoirs (Table 2).

At the background of documents from Slovak Water Management Enterprise irrigation systems in the Slovak Republic have been built on an area
Table 2. Overview of small water reservoirs in the sub-basins SR

\begin{tabular}{|c|c|c|c|}
\hline $\begin{array}{c}\text { International } \\
\text { river catchment } \\
\text { watershed }\end{array}$ & $\begin{array}{c}\text { Partial river } \\
\text { catchment } \\
\text { watershed }\end{array}$ & $\begin{array}{c}\text { Area } \\
{\left[\mathrm{km}^{2}\right]}\end{array}$ & $\begin{array}{c}\text { Number } \\
\text { of reservoirs }\end{array}$ \\
\hline Danube & Morava & 2282 & 14 \\
& Danube & 1158 & 16 \\
& Vah & 18769 & 67 \\
& Hron & 5465 & 34 \\
& Ipel' & 3649 & 16 \\
& Slaná & 3217 & 17 \\
& Bodrog & 7272 & 24 \\
& Hornád & 4414 & 8 \\
& Bodva & 858 & 2 \\
\hline Wisla & Dunajec & 1950 & 5 \\
\hline Slovakia total & & 49034 & 203 \\
\hline
\end{tabular}

of 319000 hectares, and to ensure the source of water irrigation they were supplemented with 486 service stations. This figure roughly corresponds with the number of irrigation structures. (Heldi, 2004). The bulk of the small water reservoirs for irrigation needs were built between 1958 and 1970. Then, the pace of construction declined gradually (Simoník, 2004). Once we would like to evaluate the usage of irrigation systems after 1989 , then there is an interesting piece of information that the total area of functional irrigation systems, in 2002 covered approximately 280,000 hectares. The impact of those effects is evident from the fact that from the storage area of 214 thousand hectares only 34 thousand hectares were actually irrigated, which is $15.76 \%$ of the leased acreage. The scope of irrigation utilisation and its gradual reduction is shown in Figure 1.

From the analysis of water reservoirs built up to this day we obtained information about 198 water reservoirs in Slovakia. Some are not complete, but we will try to complete them in the future. Based on available information, we can provide information about the realized constructions.

The catchment area is quite different. The smallest catchment area of reservoirs implemented so far was $1.2 \mathrm{~km}^{2}$ and the largest area was $117.12 \mathrm{~km}^{2}$.

The design flow $\mathrm{Q}_{100}$, for dimensioning the safety spillway and flow of flood wave through the reservoir reaches in already built reservoirs from $3.3 \mathrm{~m}^{3} \cdot \mathrm{s}^{-1}$ to $114 \mathrm{~m}^{3} \cdot \mathrm{s}^{-1}$ in the area Tulčík Záhradné on Ternianka stream.

Storage volume of small dams for irrigation varies from 2.1 thousand $\mathrm{m}^{3}$ in the lowest water reservoir to $3,352,000 \mathrm{~m}^{3}$. 


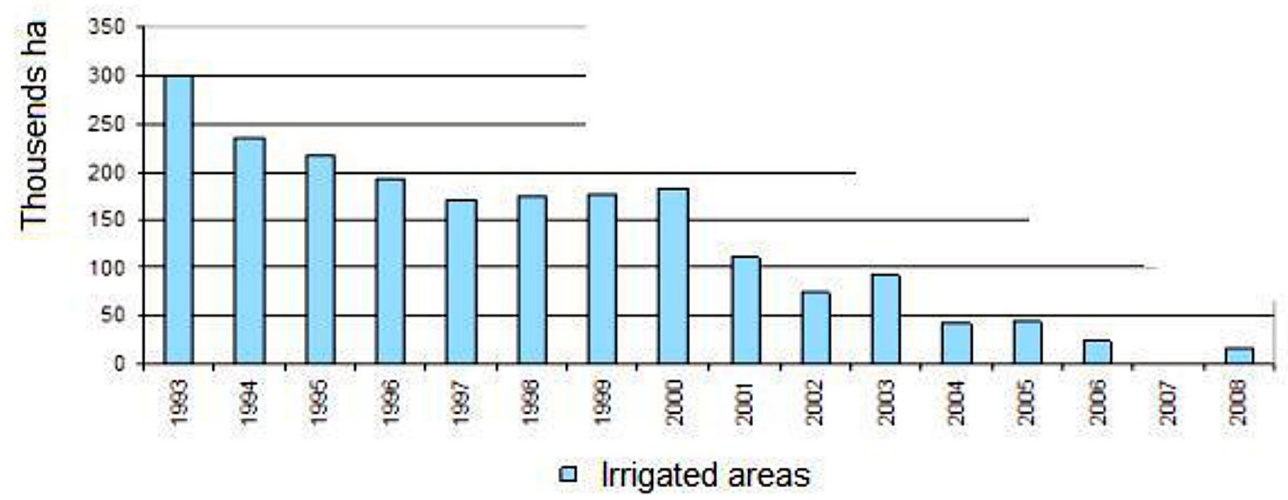

Figure 1. Irrigated area in Slovakia thousands ha [Source: SO SR]

The differences in the size of the submerged area are not substantial. The smallest submerged area extents from 1.08 hectares to 74.2 hectares.

The overview of the width of the realized dam crest is really interesting. According to the information, the crown width less than $3 \mathrm{~m}$ is used for 18 reservoirs, there are 43 reservoirs with crown width of $3 \mathrm{~m}, 15$ reservoirs have the width of 3,5 $\mathrm{m}$ dam crest, 44 reservoirs have $4 \mathrm{~m}$ wide dam crest and the rest have the width of 5 meters and some, 3 reservoirs, have the width of dam crest exceeding 6 meters.

We were not able to gain detail information about the construction of the water dam reservoirs. The greater part of the reservoirs was built up from a homogeneous earth dam and only its minor part of the heterogeneous dam. The mixture of earth, created on the site from several types of soils, available at the construction site, was used to build up some of them.

To discharge water two types of outlets were exclusively used. For the reservoirs with water depth up to $3 \mathrm{~m}$ monk outlet was almost exclusively used. For other reservoirs the outlet with closure to stem the flow was used.

A small dam is mainly the water construction and its operator is obliged to keep operating and handling procedure.

The attitude to small water reservoirs has changed recently. It arose out of their status and age, but also from changes in the society, country, economic priorities and social changes in the society. From the perspective of sustainable development, it is necessary to solve their current economic, social and environmental functions. The reservoir's economy today is based primarily on the cost of maintenance and renovation. The revenues are acquired mainly from the lease, mostly from fish farming Fishing Association. The reservoirs which were built up mostly in the period 1960-1970 are now at least 45 years old and their condition is much up to their age. In particular, the reservoir compounds as a safety spillway or outlet and diversion structure need renovation quite often. Major investments are connected with disposal of sediments. Accumulation of sediments reduces the real volume of water, creating shallow zones with overheated water and intensive growth of algae and later the growth of higher wetland plants. This leads consequently to the loss of surface area and a decrease of the protective function against floods. The problem is caused by extremely strict legislation and prolonged required working procedures and their practical application for agricultural land. But we only want to return land to the place from which it was drifted away by erosion. But the legislative point of view, such a process is impossible and this is why the water reservoirs in Slovakia and the Czech republic are full of sediments. Current conditions of water reservoirs discourage inhabitants of villages to use them for recreational purposes and they lose possibility to use their cadastre for leisure activities.

Environmental functions were based in the past on the disposal of nutrients and other dissolved substances from the water by creating biomass in the reservoir. After crossing the loading, this function may be lost and later may become a part of those substances which used to be accumulated on the bed of the reservoir leak. The content of substances totally dissolved in water may increase in and change the $\mathrm{pH}$ and other water characteristics (colour, odour). Small water reservoirs are typical for local source of water and their importance will particularly increase in the future.

Another attitude to water reservoirs is from the point of view of integrated water management. There is a need to rethink their integration into 
local, regional or national management of water resources. Managing water resources we should use mainly local indigenous resources. The process of using external resources was triggered by the water utilisation for irrigation. It was necessary to bring water in deficient areas with higher consumption of water in the solved territory from other areas with oversupply in the water balance. And today we use the same methods in industry, power engineering and supply with drinking water. Water management therefore started maintaining not only local sources but regional and even supra-regional. Water consumption is increasing also in areas with original surplus and thus water management is getting increasingly problematic. For example, there is a lack of water available for construction of cooling towers of power plants or to ensure longer operating of cooling towers, in the last decade. Thus, the method of integrated water management was adopted into water resource management. All the available resources are joined together and are compared with the needs and demands of all sectors of the economy. In the process, it is necessary to prioritize strategic goal of the state and take into consideration food security, sufficiency of drinking water but also abundance of water for biota and nature.

Another problem is the issue of climate changes. We should reconsider a change in water supply sources as well as the changes of demands or losses. Climate changes are a practical example of the problems of water resources in our country and the neighbouring countries. According to the forecasts for our country, rainfall will not be fundamentally altered only their division during the year will be changed. We should expect more precipitation in winter, when water consumption is minimal and less precipitation in summer, when water consumption is substantially higher. It is therefore necessary to accumulate water resources seasonally and this is exactly the role of small water reservoirs. In summer with fewer rainy days there are the totals of the rain much higher than average. Therefore, there is an assumption of higher flood inflow into the reservoir. For this reason, it is necessary to change the dimension of reservoirs - the protective space and safety spillway. Processing the new operating rules we have to include a new set of documentation inflow into the reservoir $-\mathrm{Q}_{50}$ and $\mathrm{Q}_{100}$ but objects are not changed and thus essentially do not meet the new conditions. It is therefore necessary to establish new methodology for adapt- ing the reservoirs to new hydrological conditions. Increased temperatures, due to climate changes, will increase the evaporation of water levels and higher water losses balance of water reservoirs.

The last view is the point of view is water management and from this point of view it is necessary to re-evaluate the new requirements for the operation of small water reservoirs as water structures. It is necessary to resolve their status as a barrier to the flow continuity and security against floods and their role in resolving droughts in the country. The Water Framework Directive is considered a fundamental water management document in Europe. Its aim is to achieve a particularly good quality of waters but also environmental friendly conditions in streams. One of the problems is created by discontinuity of water flow constructing works e.g. weirs and dams. The solution might be either the elimination of discontinuities and replacement of barriers and taking all possible measures or to construct fish passes. And this is the core problem of small water reservoirs. According to the directive they do not belong to water bodies because they have less than $0,5 \mathrm{~km}^{2}$ and therefore there is not attempt to adjustment. And there are also the interests of the owners or tenants of reservoirs, who use them to breed fish or salmon-leap and who would allow the fish to escape from the breeding pond. Water managers are also responsible for the condition of the whole construction and its components. The new hydrological conditions will require new evaluation of their dimensioning and processing the design changes. Instrumentation and control technology and new materials have been significantly changed from the years 1960-1970 and therefore they have to be incorporated into the solution of small water reservoirs. Geosynthetic materials have been successfully used to reconstruct damaged dams. It is likewise necessary to take other new regulatory closure, baffling elements and other materials. There is a must to present appropriate solutions in mass media.

A positive aspect of the usage of small water reservoirs were already partially presented in general terms. Now we have to look at the negative aspects in the full range of issues. It is necessary to depict a detail picture of the impact on key parameters: water quality and, first of all, we should mention water resources. In terms of water quality and quantity, climate changes have a significant impact on recent developments. Presumably, we have to take into consideration real facts. 
The average temperature has increased during the last century by about 1 degree of Celsius. And we can assume further increase; in terms of water reservoirs it has a direct impact on water temperatures and it increases evaporation from water surface. It may seem that it has not such a big impact. But we should be aware of consequences of the rising temperature of water and particularly eutrophication of water which is evident mainly in stagnant waters (lakes, ponds and reservoirs). From the point of view of hydrobiology and fishing perspective, eutrophication in certain circumstances may be a positive phenomenon increasing productivity and profits of fish reservoirs. Natural eutrophication can lead to the so-called lake aging (it causes their degradation). It is a very slow natural process of gradual transformation of originally oligotrophic to eutrophic lakes. It is manifested by a progressive accumulation of sediments of dead aquatic organisms and changes in the chemical composition of water.

Eutrophication is the result of gradual degradation of surface waters. Their high carrying capacity is manifested by increased production of the organic material and its subsequent vigorous decomposition. This phenomenon causes other adverse events, such as the depletion of water and the oxygen-enrichment of ammonia, hydrogen sulphide, and other products of anaerobic degradation. It causes an extremely intensive development of algae and cyanobacteria are present with blooms. This phenomenon can occur through a toxic effect on aquatic organisms mentioned above. It has an adverse effect on water whose growing colouring, shrinking its utility and aesthetic properties. Strongly eutrophic water bodies cannot be used in industry and agriculture, and they are not suitable for recreation purposes. The accumulation of the above-mentioned material in water and the associated increased production of phytoplankton can cause threat of secondary water pollution created by organic substances formed by life activity of phytoplankton. In poor organoleptic properties of water and sometimes also to the formation of toxic substances which after prolonged exposure have an adverse effect on the human body (in recreational swimming they may cause rashes and inflammation of the conjunctiva) and aquatic animals as well [Virtanen, 2001].

An important source of nutrients that causes eutrophication of water can be waters poor in nutrients and atmospheric precipitations with a degree of pollution of the atmosphere caused by gases and dust. In agricultural areas, the annual rain brings about $10 \mathrm{~kg}$ of nitrogen compounds, $0,05 \mathrm{~g}$ of phosphorus and about 0.6 grams of potassium per $\mathrm{m}^{2}$ of water surface. The impact of atmospheric pollution by sulphur dioxide in rural areas impoverish the soil by rain containing about $1.0-1.5 \mathrm{~g} \cdot \mathrm{m}^{-2} \mathrm{~S}$ in industrial areas 3 , and 2 $-9.5 \mathrm{~g} \cdot \mathrm{m}^{-2} \mathrm{~S}$. This amount substantially exceeds the sulphur consumption of natural plants, to unwanted acidification of soil and thereby accelerates the release of other nutrients. Particularly dangerous sources of contaminants are products of water erosion from the territory of the original water reservoirs. These are especially various fertilizers, pesticides, and herbicides. Furthermore, sediments significantly contribute to fouling reservoirs and consequently to the reduction of the useful volume of the water reservoirs.

\section{A CONTRADICTORY OPINION TO THE ACTUAL SOURCE OR WATER SUPPLY PROBLEMS}

Both aspects can be evaluated in terms of four basic areas: social, biological, chemical and physical.

Social issues resulting from the positive and negative effects associated with the interaction of the population with water reservoirs. What is important is their location and potential subsequent use. They obviously represent a positive aspect in the direction of providing water for households, to improve human lifestyle but also biodiversity for recreational and social life, aquaculture, as well as fire protection. On the other hand, they may represent a potential threat in case of their upstream location and the possibility of breakage of the flood wave.

From a biological point of view, to support biodiversity, creating aquatic habitat protection zones encourages the emergence of bio-corridors and bio-centres. Improper management of the adjacent areas can support the development of inappropriate plants, algae and animals.

The chemical properties are extremely important. Water quality depends on the threat of reservoir surrounding, the river basin as well as residential areas, as they can bring unsuitable chemicals into the container in the collection area where the most sensitive life forms exist; in the water reservoir there is even greater risk of eu- 
trophication and could cause destruction of life in the water reservoirs and limited possibilities of using water accumulated in the water reservoirs. Unfavourable conditions of water chemistry greatly restrict the natural self-cleaning water that is currently extremely important for maintaining good status of water bodies.

When analysing the physical characteristics it is necessary to mention especially the issues related to water temperature and sediment in the water reservoir. Temperature has a significant impact on water quality in the reservoir and, on the other hand, it has a significant impact on the accumulated loss of water as vapour of the surface water. In this regard, especially in terms of small water reservoirs, riparian tree vegetation obscures the water surface and also in buffer zones around the reservoir by a peripheral rampart to prevent a direct inflow of surface water into the water reservoir.

\section{CONCLUSION}

New changes in the society, the use of irrigation as well as common European policy and its enforcement have an impact on the usage and operation of small water reservoirs in Slovakia. Water reservoirs used to serve as a positive intensive element of land utilization became a source of financial problems and environmental burdens nowadays. Their an increase in water demand is expected due to climatic changes and increased demands to solve protection against floods in the smallest sub-basins and the need of water utilisation for recreational and leisure time purposes.

The administrator of water reservoirs will need a lot more finances to reconstruct and revitalize them nowadays. The overall result will lead to the stabilization of regional water resources, as it used to be in the 17-th century in our country and other countries.

Water reservoirs, which currently represent a major source of water, may become either the source of stability of the biotopes or create the problems for the operator in the future. Each state should pay attention to stability of water resources as it will be crucially important and will help today's water reservoirs return to their original importance, even though they may be used for new purposes. The participation of water managers and engineers to promote their revival is inevitable.

\section{REFERENCES}

1. Garbrecht G. 1991. Historische talsperren. K. Wittwer, Stuttgart.

2. Heldi A. 2004. Návrh zákona o hydromelioráciách a o zmene a doplnení niektorých zákonov. Bratislava, Hydromeliorácie, š.p., pp. 20.

3. Jurík L', Húska D., Sedmáková M. 2015. Malé vodné nádrže v SR - ohrozený zdroj vody pre závlahy? Závlahy a jejich perspektiva. Mikulov. 3, 18-19.

4. Jurík L', Pierzgalski E., Hubačíková V., 2011. Vodné stavby v krajine: malé vodné nádrže. 1. vyd. Slovenská Polnohospodárska Univerzita Nitra, pp. 167.

5. Lukáč M. 2010. Historické nádrže a priehrady na slovensku v kontexte Európy a ICOLD. XXXII. Priehradné dni.

6. Mioduszewski W. 2014. Small (natural) water retention in rural areas. Journal of Water and Land Development, 20, 19-30.

7. Mioduszewski W. 2008. Budowa stawów [Ponds construction]. Warszawa, Oficzna Wydawnicza Hoża. pp. 119.

8. Pierzgalski E., Tyszka J., Szymczak T. 2002. Wpływ przyrostu lesistości i retencji zbiornikowej na zmniejszenie wezbrań $\mathrm{w}$ potokach górskich [Influence of afforestation increase and reservoir retention on decrease of high water levels in mountain streams]. Czasopismo Techniczne. Inżynieria Środowiska, 5, 141-151.

9. Simoník J., Hríbik J., Hlubina P. 2004. Rozvoj závlah po vstupe do EÚ. Slovenská Pol'nohospodárska Univerzita Nitra.

10. Šálek J., Mika Z., Tresová A. 1989. Rybníky a účelové nádrže. 1. vyd. Praha, SNTL, pp. 267.

11. Virtanen T. et al. 2001. Chémia vody. B. Bystrica, Univerzita Mateja Bela, pp. 19. 